\title{
Did the Ways Part? New Models in Judaean/Christian Relations
}

\author{
MichaEL KOK \\ $2^{\text {nd }}$ Year MA, Religious Studies \\ University of Alberta \\ Edmonton, Alberta
}

Two major religious traditions emerged out of the complex matrix of Second Temple Judaisms: Rabbinic Judaism and centrist Christianity. Traditionally, scholarship on the relationship of early Judaism and Christianity has posited an official break in the late first century $\mathrm{CE}$, especially due to the supposed imposition of an excommunication formula (B. Ber 28b-29a) at Yavneh that effectively excluded Christians from the synagogue. Statements in the Gospel of John and Justin Martyr's Dialogue with Trypho, and later Epiphanius and Jerome, appeared to confirm this thesis. The Adversus Ioudaios literature, which defines the Christian community as a people (genos) or nation (ethnos) in direct continuity with the legacy of Israel, but with Judaism positioned as the adversarial foil, is taken as another datum in support of a decisive "Parting of the Ways." In contrast, I intend to show why this model is not the best picture of Judaean ${ }^{1}$ and Christian interactions in the first few centuries. Rather than view this period through the later lens of Rabbinic Judaism and Nicaean Christianity, many diverse groups on the Judaeo-Christian spectrum were just beginning to formulate their own distinctiveness in the second century. Certain religious elites attempted to establish a normative identity and discursively construct sharp differences between Christians and Judaeans.

\footnotetext{
${ }^{1}$ I have become convinced that Ioudaios should be rendered as "Judaean" rather than "Jew" because ethnicity and religion were intertwined in the ancient world and, like other ethnic groups, Judaeans would have been identified with their place of origin. See further, Steve Mason, "Jews, Judaeans, Judaizing, Judaism: Problems of Categorization in Ancient History," JSJ 38 (2007): 457-512.
} 


\section{The "Parting of the Ways" Model}

The traditional "Parting of the Ways" model portrays Judaism and Christianity as diverging quite rapidly between 70 and $135 \mathrm{CE}$ to form two separate religious traditions. ${ }^{2}$ Scholars who accept this historical reconstruction generally recognize that Second Temple Judaism was a diverse phenomenon. Still, Dunn detects that four pillars underlie the different expressions of Second Temple Judaism: monotheism, election, Torah as covenant charter, and land focused on Temple. ${ }^{3}$ Christians eventually denied all four of these alleged pillars. Various Christian writings either polemicize against the Temple (e.g., Mark 11:17; Acts 8:48-50; Barn. 16:3-4) or identify Christ or the ekklēsia (church) as the true Temple (e.g., John 2:19-22; 1 Cor 3:16; Rev 21:22). Christian universalism challenged the notion of election and covenant markers such as circumcision, food laws and Sabbath that divided Judaeans from the other nations. ${ }^{4}$ Finally, the full identification of a human with the god of Israel (e.g., John 1:1; 20:28) placed Christians outside the limits of "mainstream" Judaism. Evans cites the divinization of Jesus, the increasingly Gentile membership in the church, the marginalization of Torah-observant Christians, the use of different versions of the scriptures (the LXX) and the impact of the two failed Judaean revolts against Rome as reasons why a schism was inevitable. ${ }^{5}$

\footnotetext{
${ }^{2}$ See James D.G. Dunn, The Partings of the Ways Between Christianity and Judaism and their Significance for the Character of Christianity, 2nd ed. (London: SCM Press, 2006); idem, ed., Jews and Christians: The Parting of the Ways, AD 70 to 135 (Cambridge: Eerdmans, 1992); W. Horbury, Jews and Christians in Contact and Controversy (Edinburgh: T\&T Clark, 1998).

${ }^{3}$ Dunn, The Partings of the Ways, 26-47.

${ }^{4}$ Dunn finds this revolution already underway with Paul's attack on "a covenantal nomism which insisted on treating the law as a boundary round Israel, marking off Jew from Gentile, with only those inside as heirs of God's promise to Abraham" (The Partings of the Ways, 182).

${ }^{5}$ C.A. Evans, "Christianity and Judaism: Partings of the Ways," in Dictionary of the Later New Testament and Its Development, ed. Ralph P. Martin and Peter H. Davids (Downers Grove: InterVarsity Press, 1997), 162-167.
} 
According to the rabbinic myth of origins, Yohanan ben Zakkai obtained permission from Vespasian to establish an academy at Yavneh after the Temple's demise in 70 CE. Shortly thereafter the Rabbis are portrayed as exerting the dominant influence over the subsequent history of Judaism. ${ }^{6}$ Schiffman infers that the Temple's destruction ended the Sadducees power base and that the Romans decimated the Dead Sea Sect and similar messianic and apocalyptic groups. ${ }^{7}$ Only the Pharisees "would adapt to the new political realities and emerge as the internal rulers of the Jewish people of Palestine."8 The Christians were the only remaining alternatives to the Rabbis, but their Christology and soteriology became unacceptable to the emerging rabbinic orthodoxy. Christians, along with other religious opponents, were allegedly censured in the synagogue by the introduction of a liturgical malediction. A beraita in the Bavli records how Gamaliel II requested Samuel ha-Qatan to formulate a "blessing" (= curse) against the minim (heretics) to become part of the 'amidah (eighteen benedictions) at Yavneh (B. Ber 28b29a). The most controversial witness, discovered at the Cairo Genizah, reads:

For the apostates let there be no hope. And let the arrogant government be speedily uprooted in our days. Let the notzrim and the minim be destroyed in a moment. And let them be blotted out of the Book of Life and not be inscribed together with the righteous. Blessed art thou, O Lord, who humblest the arrogant. ${ }^{9}$

\footnotetext{
${ }^{6}$ For the classic treatment that accepts the essential historicity of these accounts, see M. Simon, Verus Israel: A Study of the Relations between Christians and Jews in the Roman Empire (A.D. 135-425), trans. H. McKeating (Oxford: Oxford University Press, 1986), 13-14.

${ }^{7}$ Lawrence Schiffman, Who Was a Jew?: Rabbinic and Halakhic Perspectives on the Jewish-Christian Schism (Hoboken, NJ: Ktav Publishing House, 1985), 3.

${ }^{8}$ Ibid., 3.

${ }^{9}$ The translation is from Reuven Kimelman, ("Birkat Ha-Minim and the Lack of Evidence for an AntiChristian Jewish Prayer in Late Antiquity," in Jewish and Christian Self-Definition: Volume Two [ed. E.P. Sanders, A.I. Baumgarten and Alan Mendelson; Philadelphia: Fortress Press, 1981], 226). For the initial publication, see S. Schechter, “Geniza Specimens," JQR o.s. 10 (1898): 657, 659.
} 
The anticipation that both the imperial government and religious "deviants" such as apostates, minim (heretics) and notzrim (Christians) would be recipients of divine judgment seems to juxtapose two separate motifs. ${ }^{10}$ But Horbury correctly maintains that the principal focus is on the minim. The title "Of the Minim" instead of "Of the government" became standard and tradition strongly regards the prayer as an antiheretical measure. ${ }^{11}$ Although it is unlikely that anyone who attended the synagogue would have regarded himself or herself as a heretic, those who consciously opposed the Rabbis may have felt threatened by the benediction and would not voluntarily place themselves in the way of a curse. Since members of the synagogue who suspected that they were implicated in this curse may have been reluctant to pronounce the prayers, anyone who erred reciting the benediction was discredited as a $\min$ (B. Ber 29a). ${ }^{12}$

There remains a long scholarly tradition of finding Christians to be the primary referent behind the twelfth benediction. Horbury believes that Second Temple Judaism was characterized by zeal against apostasy and that the birkat ha-minim was only the climax of the long history of hostility towards Christ followers (e.g. Mark 13:9; Gal 1:1314; 1 Thess 2:14-16, Acts 21:27-32). ${ }^{13}$ As Christianity became a missionary rival to Judaism, a curse against Christians was designed to deny Christian pretensions to the covenant. ${ }^{14}$ Simon also judges Gentile Christians to be the minim par-excellence and

\footnotetext{
${ }^{10}$ Philip S. Alexander (“"The Parting of the Ways' from the Perspective of Rabbinic Judaism," in Jews and Christians: The Parting of the Ways A.D. 70 to 135, ed. James D.G. Dunn [Grand Rapids: Eerdmans, 1999], 7), suggests a curse against the minim was added to an early prayer for the overthrow of Israel's enemies. Horbury (Jews and Christians, 88-89), also speculates about an original anti-Seleucid prayer. However, in the absence of earlier textual evidence this cannot be demonstrated with any certainty.

${ }^{11}$ Horbury, Jews and Christians, 93-95. Failure to recite certain creedal affirmations (e.g. "who givest life to the dead" or "who buildest Jerusalem") could lead to the charge of minut (J. Ber 5:4, 9c).

${ }^{12}$ Alexander, "The Parting of the Ways," 9.

${ }^{13}$ Horbury, Jews and Christians, 98. Horbury perceives the phrase, "Anathema Iēsous" (1 Cor 12:3) as an early synagogue curse against Jesus to test the loyalty of its members (Jews and Christians, 27).

${ }^{14}$ Ibid., 101.
} 
always lurking behind Rabbinic disputes regarding two powers in heaven or the oral Torah, in spite of his translation of min as "kind" or "species" (the equivalent of genos) and acknowledgement that it could refer to any dissident body (J. Sanh 10:6). ${ }^{15}$ At least two pericopes explicitly identify a min as a disciple of Jesus: in one story a min attempts to heal in the name of Jesus ben (son of) Pantera (T. Hull 2:22ff, J. Shabb 14:4) while in another R. Eliezer is arrested on a charge of minut after hearing forbidden teachings in this same name (T. Hull. 2:24). ${ }^{16}$ His argument could be further substantiated if gilyonim in T. Yadayim 2:13A and T. Shabbat 13:5 refers to the gospels (cf. the Rabbinic deformation of euangelion as 'aven galayon in B. Shabb 116a). ${ }^{17}$ The gilyonim along with other heterodox works (sifrei minim) do not defile the hands, hence are not sacred, and are to be consigned to the flames. If notzrim was originally included in the birkat haminim, it would make the equation of the minim with Christians explicit.

Christian writings may further supplement this interpretation of the birkat haminim, particularly the Gospel of John and Justin Martyr's Dialogue. John insists that Christians were banned from the synagogue (John 9:22, 12:42, 16:2) and Justin repeatedly complains of curses against Christians (Dial. 16, 93, 95, 96, 108, 123, 133). The historical context for the writing of John's Gospel has been linked with the twelfth benediction since the very influential study by J. Louis Martyn. ${ }^{18}$ John uses the word aposunagōgos to describe how the Judaean authorities expelled Christians from the synagogue (John 9:22, 12:42, 16:2). John further speaks of their Law (15:25) or their feasts $(5: 1)$. His consistent labeling of his enemies as Ioudaioi and his bitter polemic

\footnotetext{
${ }^{15}$ Simon, Verus Israel, 179-201.

${ }^{16}$ Ibid., 183-184. Pantera appears to be a corruption of parthenos (virgin).

${ }^{17}$ Alexander, "The Parting of the Ways," 13.

${ }^{18}$ J. Louis Martyn, History and Theology in the Fourth Gospel (New York and Evanston: Harper and Row, 1968), 17-41.
} 
against them $(8: 42-47 ; 12: 37-43)$ reflects a traumatic split between the synagogue and the Johannine community. Johannine Christology has been considered a major factor in the Parting of the Ways because it seemed to violate Judaism's central pillar of monotheism. ${ }^{19}$ In three separate passages Jesus is accused of blasphemy for claiming divine prerogatives or even the divine name ego eimi (5:16-18, 8:58, 10:30). John's blanket statements about being cast out of the synagogue for confessing the Christ may suggest such excommunications occurred throughout the regions known to him. ${ }^{20}$ Justin Martyr protests that the Judaeans curse Christ or Christians seven times in the Dialogue $(16,93,95,96,108,123,133)$ and four further passages lack any form of the verb kataraomai (curse) but are related in subject matter $(35,47,117,137) .{ }^{21}$ Justin further insinuates that the Romans prevented Judaeans from more intense forms of persecution (16:4). Granted, Justin's accusations may be influenced by reading Christian polemic (e.g. Acts) and the martyrdom of Christians in Judaea during the recent Bar Cochba revolt. ${ }^{22}$ Even so, Justin presumed the ways had parted and later Christian apologists appear to confirm Justin's inclination. Origen writes that Christ is still anathematized by the Judaeans (Hom. on Ps. 37, 2:8). Epiphanius writes that the synagogue repeats a prayer against the Nazarene sect thrice a day (Pan. 29:9). Jerome understands "Nazarene" as a code for all Christians (Comm. in Amos 1, Comm. in Isa. Proph. 2). Horbury asserts: “These specific (patristic) reports would claim serious consideration even if no inner Jewish corroboration had survived."23 Therefore,

\footnotetext{
${ }^{19}$ Dunn, The Parting of the Ways, 298-300; Evans, "Christianity and Judaism," 163-164.

${ }^{20}$ Horbury, Jews and Christians, 100.

${ }^{21}$ Ibid., 67.

${ }^{22}$ Stephen G. Wilson, Related Strangers: Jews and Christians 70-170 CE (Minneapolis: Fortress, 1995), 173.

${ }^{23}$ Horbury, Jews and Christians, 75.
} 
according to this academic paradigm, the process of separating Judaism and Christianity began shortly after $70 \mathrm{CE}$ and that separation was sealed after the failed messianic Bar Cochba revolt in $132-135 .^{24}$

\section{Critiques of the Partings Model}

The value of the Partings of the Ways model is that it supports the valuable ecumenical task of proclaiming Judaism and Christianity to be two distinct religious traditions that are in legitimate continuity with the biblical heritage. ${ }^{25}$ Unfortunately, there are many weaknesses with the model that make it untenable as a historical reconstruction. The first major difficulty is the problematic assumption that Rabbinic Judaism quickly became the universally authoritative branch of Judaism. It is far too simplistic to believe that all the various movements thriving in the Second Temple period disappeared. Indeed, the numerous conflicts between the Rabbis and the 'ammei ha-'ares throughout tannaitic literature and the continual struggle against the minim suggest that the Rabbis did not attain prominence until at least the third century CE and then only in Palestine. ${ }^{26}$ Nor did the Rabbis necessarily purge Judaism of any writings they may have deemed "heterodox" at Yavneh. Cohen surmises that no books were actually burned at Yavneh and writes this statement off as the rhetorical excess of Tarphon and Ishmael. ${ }^{27}$ Even if one grants all the assumptions entailed in the argument that Samuel the Lesser

\footnotetext{
${ }^{24}$ It should be noted that Dunn admits in a new foreword that he has accepted criticism that his model was too simplistic. He allows for greater complexity and that various partings occurred, "over a lengthy period, at different times and places, and as judged by different people differently, depending on what was regarded as a non-negotiable boundary marker and by whom" (The Partings of the Ways, xxiv).

${ }^{25}$ Judith Lieu, "“The Parting of the Ways': Theological Construct or Historical Reality?” JSNT 56 (1994): 106-108.

${ }^{26}$ Alexander, "Parting of the Ways," 20-21.

27 Shaye Cohen, "The Significance of Yavneh: Pharisees, Rabbis, and the End of Jewish Sectarianism," Hebrew Union College Annual 55 (1984): 42 (n. 42).
} 
crafted the Birkat ha-minim at Yavneh and intended it as an anti-Christian polemic, the Rabbis simply did not attain hegemony over all of Judaism at this early date so as to oust their religious rivals.

An even greater problem is the assumption that Gentile Christians constituted the greatest peril to the Rabbis in the late first and second century. In reality, in this period the various Gentile Christ associations were numerically inferior and lacked the prestige of antiquity. The real threats to rabbinic hegemony in the first few centuries were Judaean dissidents such as apocalypticists, gnostics and hellenizers. ${ }^{28}$ Indeed, one text lists up to twenty-four types of minim (J. Sanh. 10:6) and the term Gilyonim may cover any number of works of which the Rabbis disapproved. ${ }^{29}$ Kimelman's careful $^{2}$ philological study proves that a $\min$ in the tannaitic literature unambiguously denotes a Judaean and retains this meaning in the Palestinian Amoraic literature. ${ }^{30}$ The examples that associate a disciple of Jesus with minut (T. Hull 2:22ff, J. Shabb 14:4) only indicate that this particular min was a Judaean follower of Jesus. In the Palestinian Amoraic literature, Gentile Christians are not called minim but the "nations of the world." The "nations of the world" may falsely claim to be Israel, but the true Israel possesses the Mishnah. ${ }^{31}$ The Genizah text explicitly singles out Christians, but notzrim was probably not original to the twelfth benediction. Otherwise it would be known as the birkat ha-

\footnotetext{
${ }^{28}$ Wilson, Related Strangers, 177. For apocalyptic works, one could think of 4 Ezra, 2 Enoch or the Apocalypse of Abraham. The Apocalypse of Adam has no explicit Christian references and appears to be an example of a Judaean Gnostic work. 1 Macc 1:15 and Jub 15:33-34 oppose a hellenizing party and Philo contends with some in the Diaspora who so allegorize the Scriptures that they are no longer Torahobservant by Philo's standards (On the Migration of Abraham 86-94).

${ }^{29}$ Ibid., 177. Wilson notes that Gilyonim might simply be rendered as the margins or blank spaces of a page instead of translated as "gospels."

${ }^{30}$ Kimelman, "The Lack of Evidence," 228-230.

${ }^{31}$ Ibid., 229-230. See Pesiqta Rabbati 4.1.
} 
notzrim and notzrim would be more present in the rabbinic corpus. ${ }^{32}$ Wilson thinks notzrim was added soon after the Bar Cochba revolt based on Justin's complaints that Christ and Christians are slandered in the synagogue, ${ }^{33}$ but Justin may be reacting to popular invective or to a garbled report of the birkat ha-minim. Epiphanius and Jerome are the first to allude to a curse of the Nazarenes. ${ }^{34}$ The original Birkat ha-minim only anticipated that the minim will be removed from the covenant (i.e. the Book of Life). ${ }^{35}$ Notice that "heretics" are blotted out of the Book of Life and denied a share in the Israel of the world to come (cf. M. Sanh. 10:1), but do not forfeit their status as Judaeans. ${ }^{36}$

Since Gentiles had no share in the covenant, they were never obligated to adopt halakhah or to abandon their native deities upon attending the synagogue. Judaeans tolerated the existence of other gods so long as Yahweh was acknowledged as the highest deity. ${ }^{37}$ The LXX translators interpret Exodus 22:27 as a command not to revile "the gods" (theous) and Paul can acknowledge the cosmos as filled with many theoi (gods) and kurioi (lords) while admonishing the Corinthians to have exclusive loyalty to the creator god and Jesus (1 Cor 8:5-6). There is no reason why Gentile Christians who accepted Christ as a second divine power and did not practice Torah should be unwelcome, let alone cursed, at the synagogue. There is evidence that Gentile Christians continued to attend synagogue, as Ignatius (Phld. 6:1, Magn. 8:1), Justin (Dial. 47:4) and

\footnotetext{
${ }^{32}$ Kimelman, "Lack of Evidence," 233-234. If the term notzrim was original, its absence from the tannaitic literature (and relative absence from amoraic literature) would be inexplicable.

${ }^{33}$ Wilson, Related Strangers, 182-183. The evidence provided by Justin Martyr will be assessed in more detail below.

${ }^{34}$ Kimelman, "Lack of Evidence," 237-238. They disagree whether a Judaizing sect or Christians in general are in view; see Epiphanius (Pan. 29:9) and Jerome (Comm. in Amos 1, Comm. in Isa Proph. 2).

${ }^{35}$ Kimelman, "The Lack of Evidence," 239.

${ }^{36}$ Schiffman, Who Was a Jew, 41-46, 51-53.

${ }^{37}$ Paula Fredrickson, "What Parting of the Ways? Jews, Gentiles, and the Ancient Mediterranean City," in The Ways That Never Parted, ed. Adam H. Becker and Annette Yoshiko Reed (Minneapolis: Fortress Press, 2007), 46-47.
} 
Chrysostom (Hom. 5:4, 8:8, 9) attest. The harsh polemic against the Judaeans that characterizes the Adversus Ioudaios literature in the second century is written from an elitist Christian perspective and does not necessarily mirror actual relations between Judaeans and Christians. For instance, Barnabas' division of "us" (Christians) versus "them" (Judaeans) is a reaction to the willingness of many in his congregation to share the covenant with "them" (Barn. 4:6, 13:1, 14:1) ${ }^{38}$ Horbury recognizes the evidence for Gentile Judaizers but remains adamant that, "so long as the claims of Judaism were secured by measures disallowing Christian pretensions, Christian visitors could be regarded by Jews as witnesses to popular reverence for the synagogue, and as possible future proselytes. ${ }^{\circ 9}$ This convoluted argument does not explain why Gentile Christians would persist in attending the synagogue while knowingly being damned in the prayers.

Finally, the most significant problem for the Parting model is that the textual evidence that appears to support a decisive break between Judaism and Christianity in the period between 70 and $135 \mathrm{CE}$ comes from a much later period. No one has pressed this point as eloquently as Daniel Boyarin. Boyarin points out that the earliest reference to the Birkat ha-minim found in the mid-third-century Tosefta Berakhot 3:25 is an apologetic for why the birkat ha-minim is included in the amidah, but it does not ascribe this innovation to Yavneh. Later accounts attribute the blessing to Yavneh but also narrate the ironic legend of how Samuel the Lesser forgot his own benediction (J. Ber. 4:3, 8a; J. Ber. 5:4, 9c; B. Ber. 28b-29a). Boyarin remarks, "One might as well attempt to write the history of early Britain on the basis of King Lear, or the history of colonial

\footnotetext{
${ }^{38}$ See further Michelle Murray, Playing a Jewish Game: Gentile Christian Judaizing in the First and Second Centuries CE (Waterloo: Wilfred Laurier University Press, 2004), 50-57.

${ }^{39}$ Horbury, Jews and Christians, 101.
} 
America using James Fennimore Cooper as one's only source.” ${ }^{40}$ Boyarin treats Justin Martyr in depth, but it should be noted that other early Christian writings also do not exhibit an awareness of an excommunicatory formula in the synagogue. Paul's allusion to antagonists who curse the name of Jesus (1 Cor 12:3) is not specific enough to carry the weight of being evidence for an early formal synagogue curse. Several New Testament writings indicate that their communities faced threats and beatings from the synagogue authorities, but this is in-house punishment rather than exclusion (e.g., 1 Thess 2:14-16; Mark 13:9; Matt 10:17-20; Luke 12:11-12; Acts 5:26-42).

Nor is there any real counter-evidence from John or Justin Martyr. The evidence does most likely suggest that the Johannine community was expelled from their synagogue, but we cannot extrapolate from this isolated example the policy of all the synagogues. The birkat ha-minim would not apply to John's situation anyways, because those who insisted on a sectarian self-definition were denounced but were not expelled from the synagogue. ${ }^{41}$ There is no hint that the Johannine community left the synagogue because they could not conscientiously say the prayers and Meeks adds, "it is time to recognize that the birkat ha-minim has been a red herring in Johannine research." ${ }^{42}$ It is easy to get carried away with John's rhetoric because it exhibits a sectarian worldview that sharply divides between darkness and light, between those in the kosmos (including the antagonistic Judaean leaders and their followers) and those who have overcome it (John $1: 10-13 ; 3: 19-21 ; 12: 37-50 ; 15: 18-16: 4 ; 17: 6-19)$. In fact, John may still be

\footnotetext{
${ }^{40}$ Daniel Boyarin, Border Lines: The Partition of Judaeo-Christianity (Philadelphia: University of Philadelphia Press, 2004), 68.

${ }^{41}$ Cohen, "The Significance of Yavneh" 49-50. Interestingly, the only ones who were expelled were Rabbis who did not abide by the rules of rabbinic discourse. For example, R. Eliezer was expelled for invoking a heavenly voice and miracles in opposition to the will of the majority.

${ }^{42}$ Wayne Meeks, "Breaking Away: Three New Testament Pictures of Christianity's Separation from the Jewish Communities," in "To See Ourselves as Others See Us": Christians, Jews, "Others" in Late Antiquity, ed. Jacob Neusner and Ernest S. Frerichs (Chicago, California: Scholars Press, 1985), 102.
} 
fiercely competing with the synagogue for followers and calling out covert Johannine disciples that remain in the synagogue to reveal their allegiance to Christ (12:42-43).

Justin's repeated references to curses directed against Christians are also not unequivocal. Kimelman points out that these curses occur only four times in the context of the synagogue (Dial. 16:4; 47:5; 96:2, 137:2) and only once surrounding a prayer (137:2). The last passage uses "scoff" (episkōpsēte pote) instead of "curse" (kataraomai) or "anathematize" (katanathēmatizō) and takes place after the prayer $(137: 2) .{ }^{43}$ Justin's accusations of Judaean antagonism could just as easily reflect popular hostility towards the centrist Christian claim on the title Israel or, as Boyarin argues is the case for the Martyrdom of Polycarp, could be completely fabricated to serve his rhetorical purposes. ${ }^{44}$ On the other hand, Boyarin should allow that it is equally likely that Justin had received a confused report about the birkat ha-minim through his extensive correspondence with other Judaeans and presumed it was directed against all of the Christians. Van der Horst argues, "In the polemical situation in which Justin wrote such a misunderstanding seems only natural.." ${ }^{, 5}$ If we grant that Justin reflects indirect knowledge of a liturgical malediction, Justin still wrote a half a century after Yavneh and after the traumatic effects of the Bar Cochba rebellion as reflected in the Dialogue. ${ }^{46}$ Wilson offers the balanced judgment that "the rabbinic account of the introduction of the Birkat ha-minim is thus a retrospective, punctiliar summary of what was in reality a lengthy process." ${ }^{, 47}$

\footnotetext{
${ }^{43}$ Kimelman, "Birkat Ha-Minim," 233-234.

${ }^{44}$ Boyarin, Border Lines, 71-73; idem, “Justin Martyr Invents Judaism” Church History 70/3 (2001): 435436

${ }_{45}^{4}$ Pieter W. van der Horst, “The Birkat ha-minim in Recent Research," ExpTim 105 (1994-1995), 367.

${ }^{46}$ Boyarin, "Justin Martyr," 435.

${ }^{47}$ Wilson, Related Strangers, 181.
} 
Eventually the ways did part, but the best evidence that religious authorities attempted to mandate a strict policy of separation derives from the fourth century CE. Of course, Chrysostom's severe homilies against Judaizing practices and the increasing imperial measures against Judaism reveal that the attitudes of religious elites may not reflect the actual facts on the ground. ${ }^{48}$ Nevertheless, centrist Christianity became the official imperial cult, suppressing rival Christian identities and castigating Judaism as a false superstitio. Correspondingly, we have evidence that the birkat ha-minim broadened to include Gentile Christians. Kimelman points out the shift in meaning of the term $\min$ in Babylonia to encompass non-Jews. In the Bavli we first hear the expression " $m i n$ among the nations" (B. Hull 13b). ${ }^{49}$ Boyarin clearly articulates the difference: "Since Christianity itself is no longer a threatening blurring within but a clearly defined without, minut comes now simply to mean the religious practices of the Gentiles, the Christian Romans."50

This is corroborated by the allusions in Epiphanius and Jerome to a thricerepeated petition against the Nazarenes. ${ }^{51}$ Kimelman suspects Jerome's desire to place Judaism in a pejorative light caused him to (mis)interpret the birkat ha-minim as a curse towards all Christians and judges that Epiphanius correctly understood notzrim to be a reference used exclusively for Judaizing Christians. ${ }^{52}$ But the fact that notzrim is a frequent post-Talmudic reference for all Christians makes Kimelman's suggestion

\footnotetext{
${ }^{48}$ In $315 \mathrm{CE}$, Constantine enacted a law mandating harsh punishments for converts to Judaism. In 339, Constantius outlawed intermarriages and Theodosius forbade the building of new synagogues in 439 .

${ }^{49}$ Kimelman, "The Lack of Evidence," 230-232. The parallel passage in the Yerushalmi uses the term goy (J. Yeb. 8:1,8d).

${ }^{50}$ Boyarin, Border Lines, 220.

${ }^{51}$ See Epiphanius (Pan. 29:9) and Jerome (Comm. in Amos 1, Comm. in Isa Proph. 2).

${ }^{52}$ Kimelman, "The Lack of Evidence," 237-38.
} 
unlikely. ${ }^{53}$ Moreover, Jerome makes a subtle but important distinction between the sect of Nazoraeans in his epistle to Augustine (Ep. 112.13) and the term for Christians in general as Nazarenes (Comm. in Amos 1; Comm. in Isa. Proph. 1). ${ }^{54}$ A curse against Gentile Christians fits the fourth-century context: "The anti-Jewish measures taken by the Roman government that was a Christian one by now, made such a development well nigh unavoidable." ${ }^{, 55}$ It would be a mistake to study the first few centuries through the lens of fourth-century developments.

\section{Towards Establishing a New Model}

In the end, the Partings model wants to draw a straight trajectory from the late first century to Rabbinic Judaism and Nicaea in the fourth century. However, as Lieu brilliantly elucidates the matter, the problem here is that the model "operates essentially with the abstract or universal conception of each religion, Judaism and Christianity, when what we know about is the specific and local." ${ }^{, 56}$ Interpretive taxonomies enable scholars to order and classify various phenomena, but scholarly taxa can become a hindrance to the descriptive task when they obscure or even neglect primary data. ${ }^{57}$ Our categories of "Judaism" or "Christianity" are in danger of being regarded as self-evident and, worse, they may simply be prejudicial restatements of the subject's own classifications. ${ }^{58}$

Therefore, Jonathan Z. Smith urges historians of religion to adopt a more polythetic mode of classification that jettisons the notion of a single definitive feature that

\footnotetext{
${ }^{53}$ Horbury, Jews and Christians, 76.

${ }^{54}$ Schiffman, Who Was a Jew, 57-60; van der Horst, "The Birkat ha-minim," 367.

${ }^{55}$ Horst, "The birkat ha-minim," 368.

${ }^{56}$ Lieu, "Parting of the Ways'," 8.

${ }^{57}$ Jack N. Lightstone, The Commerce of the Sacred: The Mediation of the Divine among Jews in the GrecoRoman World (rev. and enl. ed.; New York: Columbia University Press, 2006), 1-2.

${ }^{58}$ Ibid., $1,4$.
} 
must be possessed by every item in the class. ${ }^{59}$ It is impossible to speak of the "pillars of Judaism" when Judaeans could not agree on a basic identification marker like circumcision. ${ }^{60}$ Boyarin has supplied a new conceptual model that has great heuristic value for studying early Judaean/Christian interactions. Appealing to wave-length theory, Boyarin posits a wide variety of beliefs represented on the Judeo-Christian spectrum ranging from Marcionites to non-Christian Judaeans to everyone else in the middle. Gradually this wide assortment of religious dialects developed into clusters through diffusion and eventually organized to become the "official" religions of Rabbinic Judaism and orthodox Christianity. ${ }^{61}$

In the first few centuries many diverse Judaean and Christ associations were engaging in "social formation and mythmaking" 62 in an attempt to articulate their own identities. The Rabbis represented one voice on this Judaeo-Christian spectrum. It is not unlikely that the Rabbis responded to this internal diversity by convening an academy at Yavneh and outlining the principle that multiple viewpoints can represent "the words of God" (B. 'Eruvin 13 b and parallels) in a bid to end sectarianism. ${ }^{63}$ Boyarin's view that

\footnotetext{
${ }^{59}$ Jonathan Z. Smith, "Fences and Neighbours: Some Contours of Early Judaism," in Approaches to Ancient Judaism: Volume Two, ed. Willaim Scott Green; Brown Judaic Studies 9 (Chico: Scholars Press, 1980), 4-5.

${ }^{60}$ Smith, "Fences and Neighbours," 10-15. Circumcision was the quintessential marker of the covenant in the priestly tradition (Gen 17:9-14, Exod 12:43-49). Paul divides humanity between circumcised and uncircumcised, but vigorously opposes Gentile proselytes getting circumcised (Gal 6:15). Josephus notes that circumcision was part of the ancestral ways (Ant. 20.41, 46), but both Josephus and Philo defend circumcision by noting the parallel Egyptian practice (Ant. 1.214; Spec.Leg.1.2). Finally, there was a significant hellenizing, anti-circumcision party (1 Macc 1:15; Jub 15:33-34).

${ }_{61}^{61}$ Boyarin, Border Lines, 18-19.

${ }^{62}$ This useful conceptual vocabulary was introduced by Burton Mack, Who Wrote the New Testament? The Making of the Christian Myth (San Francisco: HarperSanFrancisco, 1995), 11.

${ }^{63}$ Cohen, "The Significance of Yavneh," 27-53. Boyarin (Border Lines, 158-159), considers this dialectic to be a late development, but ignores the fact that the principle that multiple views can be the "words of God" is found three times in the Yerushalmi (J. Yevamot 1, 3b; J. Berakhot 1, 3b; and J. Kiddushin 1) and only in the Yerushalmi is it associated with Yavneh. The principle seems at least implicit in the Mishnah. See the critical review of Boyarin by Stuart J. Miller ("Roman Imperialism, Jewish Self-Definition and Rabbinic Authority" Association of Jewish Studies Review 31 [2007]: 354).
} 
Yavneh is a late rabbinic myth of origins projected onto the first century ${ }^{64}$ is unduly skeptical because it relies too heavily on theological discourse and not enough on concrete historical events. Even if the narrative surrounding Yavneh is shrouded in legend, Cohen is more convincing in his contention that Yavneh was a creative response to the radical impact of the destruction of the Temple in $70 \mathrm{CE}$. Since the temple cult often was the seat of sectarian difference, its demise led the Rabbis to try to resolve the problem of sectarianism with intensive study of the Torah guided by rabbinic rules of interpretation and discourse. ${ }^{65}$ The Rabbis still had to contend with rival movements on the Judaeo-Christian spectrum that wanted to implement their own visions for Judaism.

We must leave behind definitions of orthodoxy that have been established by the winners of these historical contests. Experimenting with binitarianism or a divine-man Christology did not place Christ followers outside the boundaries of early Judaisms. High Christology appears far earlier than the usual posited period for the Parting of the Ways (70-135 CE). Paul quotes an early Aramaic prayer to Jesus (1 Cor 16:22b), records early Christological hymns (e.g. Phil 2:6-11), adapts the Shema to include both "one God" and "one Lord" (1 Cor 8:6) and transfers scriptural references about Yahweh to Jesus (Rom 10:13, 1 Cor 1:31, 2 Cor 3:16, 10:17, 1 Thess 4:16). Larry Hurtado has done the most extensive survey of early cultic veneration of Christ, which he styles as a "mutation" of Second Temple monotheism. ${ }^{66}$ However, others could speculate about the plural thrones in heaven (Dan 7:9), speak about a divine hypostasis such as the logos (Word) in Philo or sophia (Wisdom) in wisdom literature (Prov 8; Wisd. of Sol. 7:22-30),

\footnotetext{
${ }^{64}$ Boyarin, "Justin Martyr Creates Judaism," 445-449; idem, Border Lines, 151-201.

${ }^{65}$ Cohen, "The Significance of Yavneh," 47-50; Miller, Roman Imperialism, 353-354.

${ }^{66}$ Larry W. Hurtado, Lord Jesus Christ: Devotion to Jesus in Earliest Christianity (Grand Rapids: Eerdmans, 2003), 64, 70-74. This cultic veneration includes prophecy in Jesus' name, baptism in Jesus' name, prayer to Jesus, hymns about Jesus (e.g. Phil 2:6-11), hope for Jesus' parousia (coming), etc.
} 
venerate a principle angel such as Yahoel (Apoc. Abr. 10:3-4, 8-17) or Metatron (B. Sanh. 38b), or accept the apotheosis of a human (e.g. Enoch in 3 En. 10:1-3). ${ }^{67}$ We simply do not know enough about how the average Judaean might have accommodated these figures in their cultic praxis.

Some Rabbis repudiated "two powers in heaven" as ditheism and an affront to monotheism. ${ }^{68}$ While the Rabbis do not expel every notion of a second power, the second divinity is completely subordinated to Yahweh. ${ }^{69}$ Some Jesus groups also deemed the full divinity of Jesus to violate strict monotheism. Justin differentiates Judaean factions that held Jesus was a man elected to be Christ from those who share Justin's Christology (Dial. 48), and later comments by Origen (C. Celsus 5.61) and Eusebius (Hist. Eccl. 3.27) lump different Judaean Jesus groups with divergent Christological beliefs under the heading "Ebionite." 70 It is possible that the Judaean group with the Christology that more closely aligned with the centrist church may have been known as the "Nazarenes" based on the description of them provided by Epiphanius (Pan. 29) and Jerome (Ep. 112.13). ${ }^{71}$ The point in this analysis is that there was no

\footnotetext{
${ }^{67}$ See further Alan Segal, Two Powers in Heaven: Early Rabbinic Reports about Christianity and Gnosticism, Studies in Judaism in Late Antiquity 25 (Leiden: E.J. Brill, 1977). Boyarin (Border Lines, 89147) includes the Memra in the Targums as equivalent to the Johannine logos, but it is more debatable whether the Memra is an actual divine hypostasis or merely a circumlocution for the divine name.

${ }^{68}$ Segal, (Two Powers in Heaven, 148-149), provides a list of biblical passages where the Rabbis engaged in exegetical battles with the minim over the doctrine of the two powers (e.g. Gen 1:26; Exod 23:21; 24:1; Dan 7:9). Evans ("Christianity and Judaism," 164), points to Rabbi Abahu's (third century) denial that God has a son (Ex.Rab. 29.5 [on Ex 20:2]) and to Rabbi Aha's (fourth century) commentary on the Shema, which excludes any second power whether son or brother (Deut. Rab. 2.33 [on Deut 6:4]) to show how some Rabbis may have responded to Christian binitarianism.

${ }^{69}$ Boyarin, Border Lines, 128-147. For instance, in B. Hagiga 15a Metraton is punished for causing the mistaken acclamation of two powers in heaven because he sat on his heavenly throne.

${ }^{70}$ R. Pritz, Nazarene Jewish Christianity: From the End of the First Century until Its Disappearance in the Fourth Century (Jerusalem, Leiden: Magnes /Brill, 1988), 19-28.

${ }^{71}$ Ibid., 29-70; also Wilson, Related Strangers, 155-157. In Acts 24:5 Paul is a ringleader of the Nazarenes, which suggests the antiquity of the name before it was overtaken by the Greek Christianos (Christian). However, Pritz goes too far in his attempt to draw a straight line from the apostolic church in Jerusalem to the Nazarenes, with the Ebionites judged as a later aberration. Justin Martyr was probably more correct in his assessment that different Judaean Christ groups had different christologies (Dial. 48).
} 
normative theology of monotheism or of divine mediation that could serve to clarify the difference between Judaean and Christian movements.

There was also no reigning orthopraxy that was universally held across the Judaeo-Christian spectrum. Scholars have abandoned the simplistic portrait of the quick marginalization of a single Torah-observant Judaean Christianity by a single antinomian Gentile Christianity that became dominant. Several different Judaean Christian sects such as the Ebionites, Elkesaites, Jacobites and Nazarenes continued to thrive. ${ }^{72}$ There was also diversity of opinion among Gentile Christians over Judaean practices. Some followed Paul's admonitions to Gentile Christ followers to not adopt ta erga tou nomou (the works of the law) (Gal 2:16; 3:2, 10; Rom 3:20, 27-28), but there is abundant evidence that Gentile Christian Judaizing flourished during the first few centuries. In Asia Minor, John the seer's condemnation of those who "say they are Judaeans and are not" (Rev 2:9, 3:9), Ignatius's warnings about Christians who practice Judaism (Phil. 6:1, Magn. 8:1), and Justin's concessions that some Gentile Christians practiced Judaean customs (Dial. 47:4) all reflect the presence of Gentile Judaizing. ${ }^{73}$ Chrysostom's vituperative sermons against Gentile Judaizing reveal that it was still very much a reality in the fourth century. Lightstone makes the following astute observation: "If in the period of the Church's triumph Judaizing flourished, how much the more so in years of persecution of the Church, when Judaism enjoyed licit status under Roman law and the prestige of antiquity, while Christianity did not!"74

Developments in the second century CE encouraged various groups on the Judaeo-Christian spectrum to present themselves as the only legitimate expression of the

\footnotetext{
${ }^{72}$ For descriptions on these groups, see Wilson, Related Strangers, 148-159.

${ }_{73}^{73}$ Murray, Playing a Jewish Game, 73-99.

${ }^{74}$ Lightstone, The Commerce of the Sacred, 92.
} 
biblical heritage and claim a normative identity. A major part of identity formation is a preoccupation with boundaries and the opposition in/out, which serves to generate an Other who exists beyond the limits of the group. ${ }^{75}$ Boyarin emphasizes that parallel developments of identity formation revolved around binitarianism. He writes, "Two Powers in Heaven became the primary heresy for the Rabbis, and Modalism, the Christian heresy par excellence, became the only 'orthodox' theology allowed to Jews."76 Other historical developments outside of theological discourse should also be considered when we consider why the various Judaean and Christian groups began to formulate tighter boundaries. Other charismatic, apocalyptic and messianic movements became increasingly suspect to the Rabbis. Apocalyptic enthusiasm may have produced the failed hopes of the rebuilding of the Temple by the "servants of the enemy" as alluded in Barnabas 16:3-4. ${ }^{77}$ Messianic fervor surrounded the disastrous revolt by Simon Bar Cochba ("Son of the Star") in 132-135 CE. Since our earliest possible evidence for the birkat ha-minim is Justin Martyr's Dialogue, it is likely that the Rabbis attempted to introduce this benediction into the liturgy in the second century in an attempt to strengthen their position of authority relative to other forms of Judaisms.

It is not a coincidence that in the same period centrist apologists also began to articulate a distinct identity relative to other Judaisms and Christianities with claims to be a new ethnos or genos (1 Peter 2:9; Ep. Diog. 1:1; 5; Athenagoras Embassy 1.1-3), the new Israel (Dial. 125:5) or the heirs of the covenant (Barn. 4:7-8; 14:1-5). ${ }^{78}$ Buell notes

\footnotetext{
${ }^{75}$ Jonathan Z. Smith, "Differential Equations: On Constructing the Other" in Relating Religion: Essays in the Study of Religion (Chicago and London: The University of Chicago Press, 2004), 230.

${ }^{76}$ Boyarin, Border Lines, 138

${ }^{77}$ Horbury, Jews and Christians, 133; Wilson, Related Strangers, 13.

${ }^{78}$ The most innovative and thorough analysis of early Christian ethnic reasoning is found in Denise Kimber Buell, Why This New Race? Ethnic Reasoning in Early Christianity (New York: Columbia University Press, 2005).
} 
that ethnic reasoning allowed Christians to take advantage of the privileges granted to other ethnic communities to practice their own native religious customs, to determine the criteria for membership in the Christian people, to engage in a universal mission and to uphold a pure form of Christian identity that excluded rival Christian identities. ${ }^{79}$ Her thesis may seem counter-intuitive, as scholars generally assume early Christians transcended ethnic and cultural barriers and identification strategies and ethnicity is usually narrowly defined in relation to ancestry and kinship. ${ }^{80}$ But in the ancient world a genos was as much defined by customs and religious praxis as by myths of origin and descent. There was no abstract conception of religion in the ancient Mediterranean, but, as Fredrickson aptly puts it, "gods also attached to particular peoples; 'religion' ran in the blood." 81 Ethnic reasoning was utilized by Christian intellectuals to differentiate centrist Christians from Judaeans, yet legitimate this new ethnos in the Greco-Roman Empire by rooting it in the antiquity of the Israelite epic. The Adversus Ioudaios literature responded to the blurred boundaries between Christians and Judaeans by inventing a "pure" Christian ethnos in contrast to a constructed Other, the Israel kata sarka ("according to the flesh"). The reason for the extent of the polemic against the Judaeans is because the remote Other is less threatening to a distinctive ethnic and cultural identity than the approximate Other who is not so different from "us" or even claims to be "us.",82 In conclusion, this paper is an appeal to resist anachronism when studying the formation of early Judaisms and Christianities. We should not imagine that the period

\footnotetext{
${ }^{79}$ Ibid., 2-3.

${ }^{80}$ Ibid., 9. Buell notes that the early Christians still largely conform to this narrow definition of ethnicity inasmuch as they formed fictive familial units (e.g. "brothers") whom were adopted by illustrious ancestors (Abraham, Seth, Christ) (e.g. in Dial. 11, Justin claims Christians are the true spiritual Israel and descendants of Judah, Jacob, Isaac and Abraham).

${ }^{81}$ Fredrickson, "What 'Parting of the Ways,", 39.

82 Smith, "Differential Equations," 245.
} 
between 70 and $135 \mathrm{CE}$ marked a decisive separation between two monolithic entities, Judaism and Christianity. Instead, different groups on the Judaeo-Christian spectrum continued to engage one another in an attempt to formulate their own distinctiveness. Yet certain Judaean and Christian intellectuals in the second century CE also became concerned to articulate a distinct collective consciousness and demarcate clear boundaries between insiders and outsiders. But Boyarin explains that the instability of dominating religious paradigms "necessitate their constant reproduction and the constant assertion of their naturalness and of hybridity as unnatural and monstrous."

Adherents of both Rabbinic Judaism and centrist Christianity maneuvered to establish themselves as independent entities by constructing a normative group identity and "orthodoxy." The language of syncretism, deviance or heresy was used to denote groups that continued to occupy the middle ground and transgressed these imposed boundaries. When centrist Christianity became the imperial religion, rulers attempted to legally enforce these boundaries. However, these were elite reactions that have served to disguise the actual social reality of frequent interactions between various Judaeans and Christ followers.

\footnotetext{
${ }^{83}$ Boyarin, Border Lines, 15.
} 


\section{Bibliography}

Alexander, Philip S. "'The Parting of the Ways' from the Perspective of Rabbinic Judaism." In Jews and Christians: The Parting of the Ways A.D. 70 to 135. Edited by James Dunn. Grand Rapids: Eerdmans, 1999: 1-26.

Boyarin, Daniel. Border Lines: The Partition of Judaeo-Christianity. Philadelphia: University of Philadelphia Press, 2004.

461. . “Justin Martyr Invents Judaism.” Church History 70/3 (2001): 427-

Buell, Denise Kimber. Why This New Race? Ethnic Reasoning in Early Christianity. New York: Columbia University Press, 2005.

Cohen, Shaye. "The Significance of Yavneh: Pharisees, Rabbis, and the End of Jewish Sectarianism." Hebrew Union College Annual 55 (1984): 27-53.

Dunn, James D.G. The Partings of the Ways Between Christianity and Judaism and their Significance for the Character of Christianity. $2^{\text {nd }}$ ed. London: SCM Press, 2006.

ed., Jews and Christians: The Parting of the Ways, AD 70 to 135.

Cambridge: Eerdmans, 1992.

Evans, C.A. "Christianity and Judaism: Partings of the Ways." Dictionary of the Later New Testament and It's Development. Edited by Ralph P. Martin and Peter H. Davids; Downers Grove: InterVarsity Press, 1997: 159-170.

Fredrickson, Paula. "What Parting of the Ways? Jews, Gentiles, and the Ancient Mediterranean City." In The Ways That Never Parted: Jews and Christians in Late Antiquity and the Early Middle Ages. Edited by Adam H. Becker and Annette Yoshiko Reed; Minneapolis: Fortress Press, 2007: 35-63.

Horbury, William. Jews and Christians in Contact and Controversy. Edinburgh: T\&T Clark, 1998.

Hurtado, Larry W. Lord Jesus Chris: Devotion to Jesus in Earliest Christianity. Grand Rapids: Eerdmans, 2003.

Kimelman, Reuven. "Birkat Ha-Minim and the Lack of Evidence for an Anti-Christian Jewish Prayer in Late Antiquity." In Jewish and Christian Self-Definition: Volume Two. Edited by E.P. Sanders, A.I. Baumgarten and Alan Mendelson; Philadelphia: Fortress Press, 1981: 226-244.

Lieu, Judith. "“The Parting of the Ways': Theological Construct or Historical Reality?" Journal for the Study of the New Testament 56 (1994): 101-119. 
Lightstone, Jack N. The Commerce of the Sacred: The Mediation of the Divine among Jews in the Greco-Roman World. Revised and Enlarged Edition. New York: Columbia University Press, 2006.

Mack, Burton. Who Wrote the New Testament? The Making of the Christian Myth. San Francisco: HarperSanFrancisco, 1995.

Martyn, J. Louis. History and Theology in the Fourth Gospel. New York and Evanston: Harper and Row, 1968.

Mason, Steve. "Jews, Judaeans, Judaizing, Judaism: Problems of Categorization in Ancient History." Journal for the Study of Judaism 38 (2007): 457-512.

Meeks, Wayne. "Breaking Away: Three New Testament Pictures of Christianity's Separation from the Jewish Communities." In "To See Ourselves as Others See Us": Christians, Jews, "Others" in Late Antiquity. Edited by Jacob Neusner and Ernest S. Frerichs; Chicago, California: Scholars Press, 1985.

Miller, Stuart J. "Roman Imperialism, Jewish Self-Definition and Rabbinic Authority." Association of Jewish Studies Review 31 (2007): 329-362.

Murray, Michelle. Playing a Jewish Game: Gentile Christian Judaizing in the First and Second Centuries CE. Waterloo: Wilfred Laurier University Press, 2004.

Pritz, Ray. Nazarene Jewish Christianity: From the End of the First Century Until Its Disappearance in the Fourth Century. Jerusalem, Leiden: Magnes /Brill, 1988.

Segal, Alan. Two Powers in Heaven: Early Rabbinic Reports about Christianity and Gnosticism. Studies in Judaism in Late Antiquity 25. Leiden: E.J. Brill, 1977.

Simon, M. Verus Israel. A Study of the Relations between Christians and Jews in the Roman Empire (A.D. 135-425). Translated by H. McKeating. Oxford: Oxford University Press, 1986.

Schechter, S. “Geniza Specimens.” Jewish Quarterly Review o.s. 10 (1898): 654-659.

Schiffman, Lawrence. Who Was a Jew: Rabbinic and Halakhic Perspectives on the Jewish-Christian Schism. Hoboken, NJ: Ktav Publishing House, 1985.

Smith, Jonathan Z. "Fences and Neighbours: Some Contours of Early Judaism." In Approaches to Ancient Judaism: Volume Two. Edited by William Scott Green; Brown Judaic Studies 9. Chico: Scholars Press, 1980: 1-25. 
Smith, Jonathan Z. "Differential Equations: On Constructing the Other." In Relating Religion: Essays in the Study of Religion. Chicago and London: The University of Chicago Press, 2004.

Van der Horst, Pieter W. "The Birkat ha-minim in Recent Research.” The Expository Times 105 (1994-1995): 363-368.

Wilson, Stephen G. Related Strangers: Jews and Christians 70-170 CE. Minneapolis: Fortress Press, 1995. 